\title{
Development of eco-tourism in foreign and Russian national parks
}

\author{
Elvira Rogozina, Tatiana Okonnikova, Ekaterina Pimenova, Elena Kalach, and Tatiana \\ Ovsyannikova
}

Udmurt State University, Universitetskaya str., 1, 426034 Izhevsk, Udmurt republic, Russia

\begin{abstract}
The article gives a comparative analysis of eco-tourism development in North American, European and Russian national parks. The most successful examples of eco-tourism development in Russia and foreign countries are represented. North American and European national parks are noted to be the most attractive for visitors and possess a highly developed infrastructure. There are visitor centers, rental centers, cafes, camping sites, hiking trails, signboards, etc. In Russia, such factors as shortage of specialized tour operators, lack of solid collaboration between national parks and tour operators, poor mechanisms of creating awareness among independent tourists and encouraging their involvement in eco-tourism as well as lack of effective legislative and regulatory framework harden the development of eco-tourism. High transportation costs which contribute to the overall cost of eco-travel have a negative impact on the development of tourism in general making eco-tourism even less attractive. In January 2021 a questionnaire survey was carried out in order to reveal the significance of eco-tourism, its attractiveness for the citizens of the Udmurt Republic and prospective lines of its future development. The survey, based on a questionnaire method and random sampling, involved citizens of the Udmurt Republic. According to the survey findings, the respondents consider Russia to have all the necessary conditions for the development of eco-tourism. About one third of the respondents participated in eco-tours around Russia. Their experience and level of satisfaction differ. High cost of travel, poor infrastructure and lack of independent tours are limiting factors for those who have never tried eco-tours.
\end{abstract}

\section{Introduction}

The beginning of eco-tourism dates back to the end of XIX century, when first national parks were established in North America, Crimean mountain society was founded in Russia and first hiking trails appeared. Scientific definitions were coined much later. A century later, in 1980s, a term of ecological tourism was introduced by Hector Ceballos-Lascurain. A vast amount of scientific works devoted to eco-tourism issues have been recently published, but still there is no unified terminology. It even refers to the key notion of "ecological tourism" which is usually defined in different ways and according to the goals of a researcher. More often scientific workers define eco-tourism as a complex, interdisciplinary area, combining tourism, environmental and cultural heritage protection. 
Let us consider tourism on protected areas as one of the eco-tourism directions. National parks and nature parks are the most attractive for visitors among protected areas. National and nature parks are the most democratic and multi-functional types of protected areas. First national parks were established in the USA and Canada. They are still the most popular tourist sites in these countries. In the USSR wildlife reserves were the main types of protected areas and only in 1970s first nature parks started to appear in the Baltic States, in Russia they appeared only in the beginning of 1980s of the XX century. Consequently, they are relatively new in comparison to North American and even European ones. According to the Ministry of Natural Resources of the Russian Federation there have been 51 national parks in Russia in 2021 [6].

Russia has vast resources for the development of eco-tourism. During the coronavirus pandemic, domestic tourism aimed at natural attractions has become extremely popular. Nowadays Kamchatka, Baikal, Altai, Caucasus, Karelia and other regions attract relentless waves of Russian tourists.

\section{Data and research methods}

Research methods used included: analysis and synthesis; comparative, statistical, descriptive methods; observation, question-and-answer sessions, questionnaire survey. The authors studied different national parks of Europe, North America and Russia. Besides, a close look was taken at such national parks of Privolzhsky Federal District as "Bashkiriya" National Park, "Nizhnyaya Kama" National Park, "Mariy Chodra" National Park, "Nechkinsky" National Park. The findings allowed us to make a comparative analysis of their development. While visiting the national parks, the infrastructure of visitor centers and eco-trails as well as the opportunities for independent and group tours were studied. Question-and-answer sessions with national parks' employees were carried out, brochures and books about national parks were studied and pictures of eco-tourist infrastructure were taken.

\section{Outcomes}

The International Ecotourism Society defines eco-tourism as travel to areas of relatively intact nature. The aim of the travel is to get an idea of natural and cultural and ethnographic features of the territory. The travel must be organized in an eco-friendly way in order not to disturb the ecosystem integrity. Moreover, favorable economic conditions, which make nature protection beneficial for the local community, must be provided [2].

One more notion which has recently appeared and is closely connected to eco-tourism is the notion of "sustainable tourism". It reflects the concept of sustainable development of mankind. World Tourism Organization and World Travel and Tourism Council proposed principles of sustainability in tourism. They are environmental, cultural and economic sustainability as well as sustainable development of local communities [4].

The concept of sustainable tourism implies tourist activity which is environmentally friendly and contributes to responsible attitude to natural and cultural heritage of all the participants of tourist activity. It can be reached through promoting awareness and propaganda work. These are the only ways that can help change the attitude of local communities, governmental and non-governmental organizations, and the society in general to environmental issues. Moreover, tourist activity should be beneficial for host communities in order to gain their overall support [1].

In the USA the annual revenue from eco-tourism is about $\$ 14$ billion, in Australia - \$3 billion, in Kenia - \$450 million. In Russia, eco-tourism accounts only for $\$ 11$ million. In 
201811.8 million Russian and foreign tourists visited wildlife reserves in our country. 544000 tourist visited national parks.

In 2019 the visitors to national parks and wildlife reserves in Russia outnumbered an estimated intermediate federal program index of 6.7 million and made more than 8 million. There are 5 protected areas maintaining leadership in annual tourist flows. These are Kislovodsky National Park (the Stavropol region) (2018 - 1389000 visitors; 2019 1511900 visitors), Sochi National Park (the Krasnodar region) (2018 - 1086738 visitors; 2019 - 1220753 visitors), Stolby Nature Reserve (the Krasnoyarsk region) (2018- 754220 visitors; 2019 - 1131005 visitors), Curonian Spit (the Kaliningrad region) (2018 - 471660 visitors; 2019 - 589044 visitors) and Russky Sever National Park (the Vologda region) (2018 - 461000 visitors; 2019 - 471000 visitors) [3].

Let us compare tourist infrastructure and tourist-excursion activities in foreign and Russian tourist industry. The USA is one of the eco-tourism leaders. First national parks were established in the USA and they attract the most visitors every year. They are popular not only among the Americans but also among foreign tourists. American national parks have a very convenient permit system. The permit is $\$ 80$ per private vehicle. The infrastructure includes observation decks, camp sites, eco-trails, motels, hotels, stores, etc.

Belize is acquiring leading positions in eco-tourism in the Caribbean region. The country preserved traces of Maya civilization and virgin rain forests. Belizean eco-tourism is aimed at cruise liners' passengers. We had a stop at Belize-city port during the Caribbean cruise. We were offered one of the three Mayan cities to visit - Altun Ha, Xunantunich and Lamanai. You are allowed to all the cities only accompanied by guide. We chose the furthest and the largest Mayan city in Lamanai National Park. We purchased a guided tour as the trip is rather long and makes $80 \mathrm{~km}$ by coach and about $30 \mathrm{~km}$ by motorboat through the jungles. The tour took 7 hours and cost $\$ 130$ per person. The guide is local but speaks English. During the boat trip the captain slowed down to allow tourists to take pictures of birds, iguanas and even crocodiles. In Mayan language Lamanai means "drowned crocodile". It is one of the ancient cities built 3000 years ago. The city was inhabited till the Spanish conquest in the XVI century. There are several temples in the park, the most famous of which is Mask temple. You can also watch the flora and fauna of the jungles, for instance, you can see and hear howler monkeys. Lunch is included in the cost of the tour. In spite of Belize being a poor country, tours are organized at high level.

Protected areas in Europe were established later than in North America. It was connected with heightened environmental concern in the latter half of the XX century. Main features of European protected areas are that they include not only natural sites but also urban and rural settlements [5].

Let us consider a number of national parks in Spain, Latvia, Iceland, Finland and Italy as examples of tourism development in European national parks.

The most attractive and touristy national parks in Spain are the Canary Islands national parks. And first of all, Teide and Garajonay National Parks.

Teide National Park (Parque Nacional del Teide) is a pearl of Tenerife Island and is located in its very heart. Teide is an active volcano and the highest mountain peak in Spain. Founded on January 22, 1954, it is the largest park of the Canary Islands and the oldest park in Spain [7].

The park has a wide net of designated trails, the maps of which are available at visitor centers. The most famous trails are the routs to "moon landscapes" and the volcano summit. To hike to the volcano summit prior registration is required on the park website. In 2007 Teide National Park was designated by UNESCO as World Heritage Site.

Another famous national park of the Canary Islands is Garajonay National Park (Parque Nacional de Garajonay), located in the central part of La Gomera Island. In 1981 it was granted the national park status, and in 1986 it was included in the UNESCO list of the World 
Heritage Objects. The visitor center offers the excursions around the rooms of the park's ecomuseum, craftsmen workshops, displays of guanches' household and the botanical garden. The park has an appropriate tourist infrastructure [9].

There are 4 national parks in Latvia. The most frequently visited is Gauja National Park. It is the second largest park on the Former USSR area. There are more than 500 cultural and historical sites in the park. There are some settlements on the park area such as Sigulda, Krimulda, Cesis and Turaida, the most famous castle in Latvia, that definitely worth visiting [10].

Not far from Jurmala, the most popular Baltic resort, there is Kemeri National Park, founded in 1997. It is distinguished by biological diversity, unique Kemeri meadow moor, variety of ecosystems, mineral water springs. Some time ago the place was a popular resort. Only a resort park with a pavilion and bridges, some buildings of the former sanatorium and mineral water springs that are left, remind about it [11].

Finnish national parks have always attracted nature lovers. The most popular are Syote and Oulanka National Parks. They are situated in Polar Finland, bordering Russia. Both national parks are extremely popular among local population and tourists.

Syote National Park is a perfect place for winter outdoor activities such as nordic walking, skiing, snowshoeing and even winter cycling. It combines the features of a mountain-ski resort and peace and quiet of undisturbed fir forest, which is a habitat for rare animals such as flying squirrels, golden eagles, etc. Visitors can stay at hotels and cottages and use skiing pistes. As the park is in the mountains, it makes its climate special, particularly in winter.

Oulanka National Park is an area of picturesque landscapes, thousands of lakes, rivers and waterfalls and a habitat for rear species of animals and plants. The park offers several hiking routes. The most popular is Karhunhierros or Bear trail. The route is $80 \mathrm{~km}$ and is only for trained hikers. Pieni Karhunhierros trail is, on the contrary, much shorter and is suitable even for children. We tried this trail in winter and we met groups of schoolchildren there. The route is remembered by suspension bridges, whitewater, the old watermill construction, waterfalls and winding paths. There is a visitor center in the park and designated areas for rest and fireplaces.

Iceland is distinguished by highly developed tourist infrastructure and is a paradise for eco-tourists. It is easier and cheaper to go to Iceland to do geyser-watching than to go to Kamchatka. It is easy to rent a car and travel around Iceland. Geysers, erupting up to 20 meters, volcanos, snow-white glaciers, transparent blue lakes, waterfalls are almost everywhere. Traffic infrastructure in Iceland is perfect; motorways connect almost all tourist sites. The most famous national park in Iceland is Thingvellir National Park. It is designated by UNESCO as World Heritage Site. The park is on the boundary of North American and Eurasian tectonic plates which move apart $2 \mathrm{~cm}$ a year causing frequent earthquakes in Iceland. Thingvallavatn, which is the largest lake of the country, is in the park. Admission to the park is free. The park's infrastructure includes a visitor center, a café, a souvenir shop, public conveniences and car parks.

Cinque Terre National Park ("Five Lands") is the most famous national park in Italy. It occupies a coastal area of the Gulf of Genoa in the Province of La Spezia. There you can see artificial terraces. In 1997 the cultural landscapes of the park were included in the UNESCO list of the World Heritage Objects. In the villages the remains of the medieval fortified constructions against pirate attacks survive to this day. Manarola and Riomaggiore settlements are connected by the picturesque Road of Love [12].

Let us consider some examples of eco-tourism development in national parks of Russia. The more popular the tourist destination is, the more frequently the park is visited. Kislovodsky National Park, for instance, which is located on the slopes of Dzhinalsky mountain ridge. It is very popular among the visitors of Kislovodsk sanatoriums. The park has a very informative, user-friendly and elaborate website [13]. There are numerous 
terrenkurs there. Picturesque landscapes are combined with cultural sites, including historic architecture, monuments, etc. Admission to the park is free. The park represents one of the examples of attractive eco-tourist destinations with the developed tourist infrastructure in Russia.

The Kaliningrad region is now the hottest new trend in Russia and not a single tour normally goes without visiting Curonian Spit National Park. It is located on the territory bordering Lithuania. A narrow peninsula between the Baltic Sea and the Curonian lagoon is a place of stunning views. The national park was established in 1987 to preserve the natural eco-system of the Curonian Spit and, in 2000, this area was listed as a UNESCO World Heritage Site. The unique feature of the Curonian Spit is the existence of the biggest sand bar in the world [14]. Drivers have to pay to enter the park. The park has well-developed tourist infrastructure, there are a few organized ecological trails which can be visited independently or in a group. In general, we can say that the park's infrastructure resembles European one.

An attractive model of a natural and cultural ensemble is presented in the Kaluga region. In 2010 an art park was opened on the territory of Ugra National Park including NikolaLenivets village and its surroundings. The artist Nikolai Polissky initiated it. The park is located on a vast territory of 650 hectares. There you can get to know a unique collection of architectural and artistic objects. In addition, Nikola Lenivets park is a traditional venue for "Archestoyanie", "New Media Night" and "Signal" festivals. It is the largest art park in Europe. To visit the park, you need a ticket, which can be purchased at the entrance to the art park. The entrance ticket costs 400 rubles. It is a combined ticket that includes a visit to Ugra National Park and "Nikola-Lenivets" art park [15].

Stolby Nature Reserve is a favorite vacation spot for Krasnoyarsk residents. It is conveniently located; you can get there by city bus. The recreational zone is annually visited by about 1 million people, and the number of tourists per day can reach up to 20 thousand. "Stolby" has become a brand object of the Krasnoyarsk region and its capital. The park has an excellent tourist infrastructure. It is equipped with wooden paths, garden-houses for picnics, toilets, notices and signs. About $90 \%$ of independent tourists visit the territory and organized groups account only for $10 \%$ [16].

A good example of well-developed tourist infrastructure is Olenyi Ruchyi Nature Park in the Sverdlovsk region. There are several routes in the park, the most popular of which is a short route with several attractions. One of the most picturesque places in the park is Kissing Rocks. By a specially equipped ladder you can descent to the Angel of the United Hope sculpture. The route also includes Mount Svetlaya, an ancient man's camp in a cave, a Dyrovaty stone and a suspension bridge. The trails are equipped with handrails, stairs and wooden decks. The infrastructure reminds Finnish parks.

Since the last year Baikal has become a place of Russian tourists' pilgrimage. The main tourist flow falls on the Irkutsk region and Pribaikalsky National Park located in it. The park was established on February 13, 1986. It stretches $500 \mathrm{~km}$ along the Baikal coast. Pribaikalsky National Park is a place of stay of the bulk of domestic tourists and international travelers visiting Baikal [17]. We visited Baikal in March 2020 to see the amazing and unique ice of the lake. Despite the rapidly growing tourist flow, the local infrastructure leaves much to be desired. At the same time, prices are steadily rising. On average, the price per person for 5 to 7-day group tour starts from 50 thousand rubles. As the residents of Irkutsk say, even for them it is expensive to have a rest on Lake Baikal, and it is easier and cheaper to fly to Thailand. There are three main places to see the Baikal ice: Listvyanka, Bolshoye Goloustnoye and Olkhon Island. Listvyanka is the closest to Irkutsk and most tourists come there. From Irkutsk to Listvyanka, there are $70 \mathrm{~km}$ by the Baikal motorway lined with hotels, country houses and cottages. You can visit the Taltsy ethnographic museum, as well as take a walk along the beautiful embankment next to the Legend of Baikal restaurant. In Listvyanka there is a market, cafes, souvenir shops, accommodation facilities and a museum of Lake 
Baikal. Tourists go to Bolshoye Goloustnoye to see bubbled ice. The road from Irkutsk to Bolshoye Goloustnoye has a length of about $120 \mathrm{~km}$. There is a motorway to Maly Goloustnoye, and then a dusty dirt road begins. In winter, there is a skate rental on the lake. Olkhon Island is the most attractive for tourists. There you can admire the capes and ice grottoes. It is $260 \mathrm{~km}$ from Irkutsk, but there is no completely paved road to it, which also makes it difficult to visit.

Another popular place for eco-tourism in Russia is the Altai mountains. The mountains of Altai attract tourists with picturesque landscapes, pristine nature and healing air. The territory of the Altai mountains is covered with undisturbed forests, famous for rare medicinal plants and mineral springs. One of the most developed protected areas in Russia is located there. Almost a quarter of the territory of a constituent entity of the Russian Federation is occupied by specially protected natural areas, including Saylyugemsky National Park, which is especially attractive for tourists, Altaysky and Katunsky State Natural Biosphere Reserves and others [18]. Tourism in Altai is developing rapidly, modern hotels and glampings have recently appeared there, but the farther to the south and closer to the border with Mongolia and China you are, the less well-equipped accommodation facilities become. Local residents or tourist centers charge an entrance fee to many natural sites, such as, Geyser Lake, Mars, Lake Aya. The Chuisky and Chemalsky motorways have the best transport infrastructure. On the rest of the area you can often see dirt roads.

The parks of Privolzhsky Federal District are less popular with tourists. In the Republic of Mari El, there is Mariy Chodra National Park. The natural complex located on Maple Mountain consists of broad-leaved and needle-leaved forests undisturbed by civilization. Natural attractions are successfully combined with historical and cultural sites. For instance, the centuries-old oak, which is called Pugachevsky, is especially popular among visitors. According to the legend, during the peasant war of the 18th century Emelian Pugachev himself sat under it [19].

An interesting natural object is located on the territory of the Republic of Bashkortostan. It is Bashkiria National Park. Its creation is due to the need to preserve a unique complex of natural origin, which consists of mountainous South Ural forests and geological objects in the form of caves and karst sinkholes. The Muinak-Tash natural boundary with a rock-outlier, the Kutuk-Sumgan natural boundary, a karst bridge formed due to the peculiar flow of the Kuperlya stream are popular among tourists. The Nugush reservoir is also a favorite vacation place for tourists. There are some types of accommodation there. You can spend a night in the village of Nugush and several recreation centers located around the reservoir. But the eco-trails, unfortunately, are not fully designated, and the visitor center does not work at weekends and on holidays, when there is the main flow of tourists [20].

The next national park that will be discussed is Nizhnyaya Kama National Park in the Republic of Tatarstan. It was decided to establish it in 1991 due to the need to preserve and restore forest areas and floodplain meadow communities. On the area of the park there are hiking and water routes, for example, "Krasnaya Gorka", "Maly Bor", "Svyatoy Klyuch" and others. All of them are distinguished by good infrastructure, the presence of signboards. Tourist interest to the natural heritage of Nizhnyaya Kama National Park is explained by the well-known cultural and historical sites that the region is rich in. For example, the route "Shishkinsky Krai" follows the places that are reflected in the work of the famous Russian artist Ivan Shishkin, a native of the city of Elabuga [21].

In the Udmurt Republic, the only federal protected area is Nechkinsky National Park. The park was created to preserve the diversity of wildlife, as well as historical and cultural complexes and sites of the Middle Kama region. About $70 \%$ of species of flora and fauna of Udmurtia are recorded on the territory of the park. Several ecological tourist routes have been developed and operate in the park [22]. The infrastructure of the national park is well developed. It has its own hotel, a spa center and food outlets. This year, glamping is going to 
appear on the territory of the Nechkino resort, which, in turn, will increase the influx of visitors choosing eco-tourism.

In order to determine the attractiveness of ecological tourism for residents of Udmurtia, as well as to identify its promising trends, in January 2021 a study was carried out in the form of a questionnaire survey. It involved 200 people between the ages of 18 and $70,55 \%$ of which were women and $45 \%$ were men. The sample was random. The questionnaire included 11 questions. The survey results are presented below.

The concept of ecological tourism is familiar to $70 \%$ of the respondents.

For $16 \%$ of the respondents, eco-tourism is a type of tourism that is environmentally friendly; when defining it, $14 \%$ of the people questioned focused on environmental education and enlightenment. For other $10 \%$ of the respondents ecological tourism is associated primarily with travel to unique natural places, the study of rare plants and animals. $60 \%$ of the respondents considered the concept of eco-tourism as a combined notion of all the options above.

When asked about the conditions for the development of ecological tourism in Russia, $87 \%$ of the respondents answered in the affirmative way, $10 \%$ chose a negative answer. Another $3 \%$ of the respondents could not decide and chose the option "I don't know".

$35 \%$ of the respondents have already been on ecological tours and excursions in Russia, $65 \%$ of the respondents have never taken part in them.

The next question was addressed to those who had previously chosen the "no" option, that is, who had never been on ecological tours. We tried to find out the reason that prevented them from doing it. The answers distributed as follows: a) the place is far and expensive to travel - 27\%; b) undeveloped tourist infrastructure - 13\%; c) lack of independent tours - 3\%; d) lack of information about eco-tours - 7\%; e) all mentioned above - $46 \%$.

The sixth question of the questionnaire was intended for those respondents who had already been on ecological tours in Russia. They had to indicate which national parks and other protected areas they visited. The places distributed as follows: "Sochi" National Park 40\%, "Kislovodsky" National Park - 16\%, "Curonian Spit" National Park - 15\%, "Nechkinsky" National Park - 13\%, Altai mountains - 9\%, Baikal - 4\%, Kamchatka - 2\%, other areas $-1 \%$.

Next, it was found out to what extent the travelers were satisfied with the organization and service in ecological tours in Russia on a 5-point scale, where 1 means dissatisfied, 5 completely satisfied. The most popular was the score of 3 points. The average rating for travel organization and service was given by $35 \%$ of the respondents. 2 and 4 points were chosen by $20 \%$ of the respondents. $15 \%$ of the visitors were completely satisfied. $10 \%$ of the respondents remained unsatisfied with their eco-tours.

When asked about natural sites in Russia that the respondents would like to visit, the following answers were received: Kamchatka - 40\%, Baikal - 37\%, Altai - 20\%, other places $-3 \%$.

When asked about the desire to make an eco-tour in Russia or abroad, $56 \%$ of the respondents chose holidays in Russia, $40 \%$ expressed their wish to experience international travel and $4 \%$ of people questioned did not want to take part in eco-tours.

When asked about the acceptable duration of the ecological tour, the people chose a weekend tour. It was preferred by $49 \%$ of the respondents. The tour lasting 3 to 5 days was chosen by $31 \%$ of the respondents. $10 \%$ of respondents were ready to have a week tour and $7 \%$ - a two-week tour.

The last question, which was asked to the respondents, was intended to reveal places to visit or services which people would like to combine an eco-tour with. The participants' answers were as follows: a) visits to mineral springs - 35\%; b) agritourism, rural accommodation - $30 \%$; c) photo tour - $25 \%$; d) adventure tourism - $5 \%$; e) plein-air painting $-3 \%$. 
Thus, according to the findings, we come to the following conclusions. Most of the respondents are already familiar with the concept of "eco-tourism", understand its meaning and believe that Russia has all the conditions for the development of eco-tourism. At the same time, only a third of the respondents took part in eco-tours around Russia. They mainly visited national parks that are close to popular resorts such as Sochi and Caucasian Mineral Waters. Satisfaction with eco-tours is different for all respondents. Those who have not been to ecotours yet were prevented from them by the duration and cost of travel to the places of destination, the undeveloped infrastructure of the protected areas, the lack of independent tours. As it turned out, the most attractive places for tourists are places with unusual wildlife and quite remote from Central Russia such as Kamchatka, Baikal, Altai. It is interesting to note that the majority of the respondents agree to take part in eco-tours, and they choose short weekend and 3 to 5-day tours. Most of the respondents are ready to combine an eco-tour with visits to mineral springs, agritourism and photo tours.

\section{Conclusions}

National parks and other protected areas are appealing for recreation and tourism. Along with natural resources, an additional factor of their attractiveness is the historical and cultural sites available on the area, which is widely used when creating the tours. Comparison of foreign and Russian experience in tourism development in national parks shows that North American and European national parks are older and, accordingly, have the better developed infrastructure and they are more frequently visited.

The development of eco-tourism in national parks in Russia is constrained by a number of issues. One of the significant disadvantages is a high cost of transportation which tells on the cost of ecological tours. Kamchatka, Baikal and even Altai remain inaccessible to many people for these reasons. 2020 and 2021 have witnessed an increased interest in domestic tourism in Russia, but the lack of developed tourist infrastructure and appropriate services, for example, on Lake Baikal and in Altai, scares away tourists who have certain needs for comfort during their travel. A significant drawback in the activities of domestic national parks is insufficient information for potential visitors about the resources and services provided and, in general, poor promotion of protected areas as tourist destinations. Overcoming these problems can give an incentive to the development of tourism in protected areas in Russia, which will contribute to the growth of domestic tourist flow, considering anti-pandemic restrictions.

\section{References}

1. E. Cater, G. Lowman, Ecotourism. A sustainable option? (John Wiley and Sons Ltd. Chichester, 1994)

2. T. Glen Hvenegaard, J.Tour. Stud., 5, 24 (1994)

3. Y. S. Zheltyakova, Environmental Safety Management System: Proceedings of the XIV International Scientific and Practical Conference. Yekaterinburg: UrFU, 323 (2020)

4. V. S. Senin, Organization of international tourism (M.: Finance and statistics, 1999)

5. T. K. Sergeeva, Ecological tourism (M.: Finance and statistics, 2004)

6. Ministry of Natural Resources and Ecology of the Russian Federation, https://www.mnr.gov.ru/

7. Ministry of Agriculture, Fisheries and Food, http://www.magrama.gob.es/

8. UNESCO World Heritage Centre, http://whc.unesco.org/ru 
9. Ministry of Agriculture, Fisheries and Food http://www.magrama.gob.es/

10. GNP Latvija, http://www.gnp.lv/ru

11. Latvia-travel, http://www.latvia.travel/ru/

12. Parco Nazionale delle Cinque Terre, http://www.parconazionale5terre.it/

13. Kislovodsk National Park, http://kispark.ru/

14. Curonian Spit-National Park, http://www.park-kosa.ru/

15. Nikola-Lenivets camp site, http://nicola-lenivets.ru/

16. Krasnoyarsk Pillars National Park, https://www.zapovednik-stolby.ru/

17. Reserved Baikal region Pribaikalsky National Park, https://baikal-1.ru/

18. The official Internet portal of the Altai Republic, https://altai-republic.ru/

19. Mari Chodra National Park, http://www.mari-chodra.ru

20. Bashkiria National Park, http://www.npbashkiria.ru

21. Lower Kama National Park, http://nkama-park.ru

22. Nechkinsky National Park, http://nechkinsky.ru 